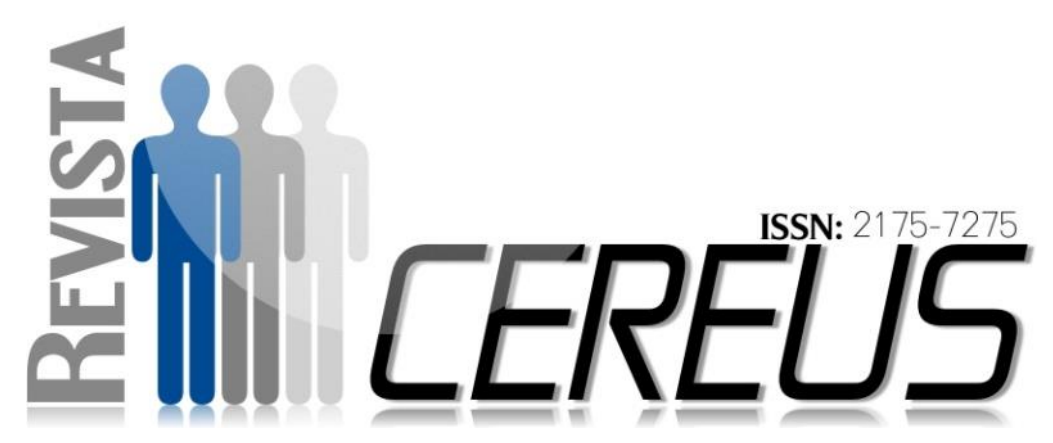

DOI: 10.18605/2175-7275/cereus.v9nep48-62.

\title{
A INFLUÊNCIA DA MÍDIA NAS DECISÕES DO TRIBUNAL DO JÚRI
}

\author{
VARANDA, Robson Ferreira, ${ }^{1}$ \\ SOUZA, Ellem Dayanne Rodrigues Vinhal ${ }^{2}$; \\ SILVA, Fábio Araújo².
}

\section{RESUMO}

O presente trabalho trata-se de uma pesquisa bibliográfica que tem o intuito de analisar sobre a influência da mídia no Tribunal do Júri, principalmente no que diz respeito à formação do juízo de valor do juiz penal e os consequentes efeitos que traz na prática processual penal. Desta forma, buscou este trabalho fazer uma abordagem acerca do Tribunal do Júri e a constituição deste instituto no ordenamento jurídico pátrio e sua efetiva consolidação e os tramites que caracterizam este Tribunal Popular, tais como a função exercida pelos jurados, os direitos e deveres destes. Em seguida, tratou de estudar a ênfase dada pelos meios de comunicação de rádio e TV aos que possui grande repercussão midiática, que geralmente resultam na alteração ou até mesmo criação de leis. A influência que a mídia exerce na sociedade é inegável. Desta forma, o trabalho em questão

\footnotetext{
${ }^{1}$ Acadêmico do curso de direito do Centro Universitário UNIRG, Gurupi - TO.

2 Docentes do Curso de direito do Centro Universitário UnirG, Gurupi-TO. E-mail: fabiosilva2020@yahoo.com.br
} 
busca mostrar como a mídia tem o poder de exercer influências nas decisões do Tribunal do Júri, principalmente quando a notícia é veiculada de forma parcial nos casos de crimes dolosos contra a vida e que obteve grande repercussão. No presente trabalho será empregado o método dialético de abordagem, analisando a relação dos veículos de mídia atualmente e o sistema penal brasileiro, especificamente no que diz respeito ao Tribunal do Júri.

Palavras chave: mídia, influência, Tribunal do Júri

\section{MEDIA INFLUENCE IN DECISIONS OF THE JURY}

\section{ABSTRACT}

This work it is a literature that aims to analyze about the media's influence on the jury, especially with regard to the formation of the criminal judge value judgment and the consequent effects that brings in criminal procedural practice. Thus, we sought this work make an approach about the jury and the establishment of this institute in the Brazilian legal framework and its effective consolidation and the formalities that characterize this People's Court, such as the function performed by the judges, the rights and duties of these. Then tried to study the emphasis given by radio and TV media to which has major repercussions media, which generally result in a change or even create laws. The influence that the media plays in society is undeniable. Thus, the job in question seeks to show how the media has the power to exert influence on the jury's decisions, especially when the news is conveyed partially in cases of crimes against life and that had a great repercussion. In this work will be used the dialectical method of approach, analyzing the relationship of media outlets today and the Brazilian penal system, specifically with regard to the jury.

Keywords: Media, influence, jury 


\section{INTRODUÇÃO}

O presente trabalho abordará sobre as peculiaridades, o surgimento e a função do Tribunal do Júri. Em seguida, será analisado também o papel da mídia, principalmente a sensacionalista e apelativa, exercem alguma influência no juízo de valor e decisão soberana do Conselho de Sentença. Para chegar a uma conclusão acerca da influência da mídia sobre as decisões do Tribunal de Justiça, foi realizada uma pesquisa bibliográfica acerca do tema.

São de competência do Tribunal do Júri os crimes contra a vida e este é composto por pessoas da sociedade, as quais assistem as matérias referentes ao crime que irão julgar, sendo alguns destes crimes comumente debatidos em rodas informais de conversa ou mostrados pela mídia. Em alguns casos, o réu já é previamente condenado, tendo em vista a exatidão em que os veículos de comunicação e os populares julgam conhecer os fatos e os mostram.

Desta forma, o princípio da presunção da inocência por vezes não é respeitado. É importante ressaltar que a lei penal brasileira considera qualquer suspeito inocente até prova em contrário. Desta forma, ninguém será considerado culpado até que se proceda com a exibição de provas, da pronúncia da defesa e da promotoria e o julgamento.

Tendo em vista a sua receptividade na sociedade, a mídia promove reportagens acerca destes atos criminosos a fim de formar opinião e vender notícia. É notável o crescimento da inclusão midiática, fazendo com que grande parte da população tenha acesso ao rádio, TV, internet e etc. $E$ quando se trata de crime, estas notícias tendem a chamar mais atenção, já que surge à curiosidade em saber do ocorrido e logo começam a discorrer sobre os fatos e muitas vezes, fazem um julgamento prévio e esperando que o judiciário faça o mesmo.

O trabalho que ora se apresenta abordará em um primeiro momento a origem a instituição do Tribunal do Júri, como funciona sua organização, quais os crimes que são de sua competência. Em seguida tratará sobre o Conselho de Sentença: os jurados, direitos, deveres, recusa e veredito das decisões. Por fim, será analisada a influência exercida pela mídia na 
decisão do Tribunal do Júri.

\section{MATERIAIS E MÉTODOS}

Foi realizada uma pesquisa bibliográfica através de revisão de literatura por meio da utilização de livros e artigos científicos disponíveis nas bases de dados Scielo, Capes Periódicos, jurisprudências e doutrinas brasileiras. A pesquisa destes materiais bibliográficos foi realizada entre fevereiro e maio de 2016.

A busca nos bancos de dados foi realizada utilizando as terminologias

\section{TRIBUNAL DO JÚRI}

Em um primeiro momento, necessário se faz abordar a origem do Tribunal do Júri. Este instituto foi constituído em 1922, como uma forma de estabelecer a democracia. Eram de competência do Tribunal do Júri as infrações penais de todos os tipos, penais e civis.

A Constituição Federal de 1988 estabeleceu em seu art. 5ํㅡㄹ inciso XXXVIII, a instituição do Tribunal do Júri com suas atribuições e competências, no entanto, limitando a sua competência apenas os crimes cadastradas nos Descritores em Direito Penal e Processo Penal, com as palavras-chaves Tribunal do Júri, Influência da mídia e imprensa. Para análise utilizamos algumas variáveis como: ano de publicação, profissão dos autores, local da pesquisa, instrumento utilizado, amostra e revista de publicação.

dolosos contra a vida. Assim está contido no referido dispositivo:

Art. 5․ [...] XXXVIII - é reconhecida a instituição do júri, com a organização que lhe der a lei, assegurados:

a) A plenitude de defesa;

b) O sigilo das votações;

c) A soberania dos vereditos;

d) A competência para 0 julgamento dos crimes dolosos contra a vida. (BRASIL, 1988).

A composição do Tribunal o Júri é: um juiz de Direito - juiz presidente, e mais 21 (vinte e um) jurados escolhidos de forma aleatória. Destes, serão escolhidos 07 (sete) jurados que irão compor 0 conselho de sentença.

Ressalte-se que, apesar da 
denominação, a lavratura da sentença não ficará por conta dos jurados. De acordo com o art. 492 do Código de Processo penal, a sentença caberá ao juiz.

O Tribunal do Júri tem a finalidade de "ampliar o direito de defesa dos réus, funcionando-se como uma garantia individual dos acusados pela prática de crimes dolosos contra a vida e permitir que, em lugar do juiz togado, preso a regras jurídicas, sejam julgados pelos seus pares" (Capez, 2009, p. 630).

Importante salientar que são de competência do Tribunal o Júri os crimes dolosos contra a vida. Entendese por dolo quando o agente tem a intenção de praticar determinado ato. $\mathrm{O}$ agente sabe que seu ato trará determinado resultado, mas mesmo assim assume os riscos por querer que este se concretize. E quase sempre os crimes dolosos são praticados com violência ou grave ameaça.

A saber, estes são os crimes contra a vida enumerados pelo Código Penal, vejamos: homicídio (art. 121 e seguintes); induzimento, instigação ou induzimento ao suicídio (art. 122); infanticídio (art. 123), aborto (art. 124 e seguintes). Portanto, estes crimes praticamos dolosamente tem seu julgamento sob competência do Tribunal do Júri.

\section{OS JURADOS DO TRIBUNAL DO JÚRI}

O corpo de jurados do Tribunal do Júri é composto por pessoas de diversas esferas da sociedade civil. No entanto, a intenção principal é que os jurados não tenham uma igualdade de princípios, desta forma, é necessário que estes sejam diferentes entre si. Quanto mais diferente um jurado do outro, mais diferenciada e democrática será sua opinião. TRIBUZY, 1992, p. 38.

\subsection{DISTINÇÃO ENTRE A MEDIAÇÃO E A CONCILIAÇÃO}

Em que pese a mediação e a conciliação serem métodos de solução consensual de conflitos estas não se confundem, uma vez que cada uma delas possui algumas peculiaridades que as difere uma da outra.

Enquanto na mediação o mediador é um terceiro imparcial que 
facilita o diálogo para que os próprios interessados cheguem a um consenso quanto à solução do conflito, na conciliação o conciliador, ainda imparcial, poderá adotar uma postura mais ativa entre as partes ao sugerir os termos do acordo.

Ao passo que a mediação é mais abrangente ao estabelecer uma convivência harmoniosa entre as partes dali para frente, a conciliação é essencialmente restrita e somente pode versar acerca dos que está intrinsicamente ligado ao litígio levado pelas partes.

Além disso, a conciliação corresponde a atividade jurisdicional que poderá ser realizada por juiz

\subsection{CONCEITO}

Os jurados formam o órgão a quem possui a atribuição de decidir sobre determinado crime e sua autoria. Conforme sua decisão soberana poderá o acusado ser condenado ou absolvido. De acordo com Maria togado ou alguém que exerça a função de conciliação enquanto que a mediação é uma atividade de natureza privada, que exige do mediador apenas a necessidade de se registrar no tribunal e aguardar sua indicação para atuar nos litígios judiciais.

O último aspecto a ser destacado acerca desses dois institutos refere-se às hipóteses de aplicação de cada um deles. Sempre que as partes conflitantes não tiverem um vínculo anterior ao litígio será utilizada a conciliação como instrumento de solução consensual, ao passo que a mediação será utilizada nos casos em as partes já tinham um vínculo antes da demanda judicial.

Helena Diniz (1998, p. 95) “o jurado é o membro do Tribunal do Júri que julga matéria de fato relativa a crime doloso contra a vida, ao responder a quesitos formulados pelo magistrado".

\subsection{FUNÇÃO}

Nos dizeres de Flávio Tribuzy (1992, p. 40) acerca a função dos jurados, entende-se que:

[...] é uma das mais elevadas e importantes, mas, por outro lado, é mais difícil e espinhosa vez que se deve decidir sobre a liberdade de uma pessoa acusada de um crime, e a liberdade são, depois da vida, o mais precioso direito do ser humano. 
Portanto, é evidente a importância da função do jurado, sendo uma das mais importantes, pois a este fica a responsabilidade de decidir sobre

\subsection{DEVERES}

O dever do jurado ao ser convocado é de atender ao chamado da justiça e comparecer no Tribunal do Júri, conforme preceitua o texto do art. 434 do Código de Processo penal "Art.

\subsection{DIREITOS}

De acordo com Júlio Fabbrini Mirabete o cidadão que cumpre o dever cívico de jurado tem direito a algumas regalias, tais como:

O cumprimento do dever cívico da função do jurado the confere determinadas regalias. É considerado serviço público relevante, estabelece presunção de idoneidade moral, assegura prisão especial, em caso de crime comum, até o julgamento definitivo (art. 295 e atribui preferencia, em igualdade de condições, nas concorrências públicas. A regalia quanto à prisão especial foi complementada pela Lei №. 7.210, de 11 de julho de 1984 LEP), com previsão de que o jurado deve cumprir pena em "dependência separada, muito embora o art. 84 da referida lei mencione o funcionário da

\subsection{RECUSA}

Assim dispõe o Código Penal:

"Art. 330. Desobedecer a ordem legal a liberdade ou não de uma pessoa e buscando agir sempre na imparcialidade com base nos fatos narrados.

434 - CPP. O serviço do júri será obrigatório. 0 alistamento compreenderá os cidadãos maiores de 21 (vinte e um) anos, isentos os maiores de 60 (sessenta)".

\section{Administração da Justiça Criminal" $\left(\S 3^{\circ}\right)$, deve-se incluir o jurado porque exerce função pública, sendo funcionário público para os efeitos penais (art. 327 do CP). (2007, p. 984)}

E ainda, o jurado terá a possibilidade de se ausentar do trabalho para prestar seus serviços à justiça sem nenhum ônus aos rendimentos, conforme preceitua o art. 430 do CPP: "o serviço do júri será obrigatório. $\mathrm{O}$ alistamento compreenderá os cidadãos maiores de 21 (vinte e um) anos, isentos os maiores de 60 (sessenta)". 
de funcionário público. Pena: detenção, de quinze dias e seis meses, e multa". Segundo Capez:

O serviço do júri é obrigatório, de modo que a recusa injustificada em lhe servir constituirá crime de desobediência. A escusa de consciência consiste na recusa do cidadão em submeter-se a obrigação legal a todos imposta, por motivos de crença religiosa ou de convicção filosófica ou política. (2009, p. 671).

\subsection{SOBERANIAS DO VEREDICTO}

Neste sentido é importante transcrever o pensamento de Tourinho Filho (2002, p. 246) quando este diz que:

Júri sem um mínimo de soberania é corpo sem alma, instituição inútil. Que vantagem teria o cidadão de ser julgado pelo tribunal popular se as decisões deste não tivessem um mínimo de soberania? Por que o legislador constituinte esculpiu a instituição do júri no capitulo pertinente aos direitos e garantias individuais? Qual seria a garantia? A de ser julgado pelos seus pares? Que diferença haveria em ser julgado pelo juiz togado ou pelo tribunal leigo? Se o tribunal ad quem, por meio de recurso, examinando as quaestiones facti e as quaestiones júris, pudesses como juízo rescisório, proferir a decisão adequada, para manter 0 júri. $O$ legislador constituinte entregou o julgamento ao povo, completamente desligado das filigramas do direito criminal e das

\section{A IMPRENSA}

Os primeiros vestígios da imprensa no Brasil datam de 1808, com

a chegada da Corte Portuguesa, onde
Sendo assim, o cidadão que for convocado para compor o corpo de jurados do Conselho de Sentença e se recusar ou se ausentar injustificadamente, terá a perda dos seus direitos políticos e podendo pegar uma pena de 15 dias a 06 meses de detenção mais multa.

súmulas e repositórios jurisprudenciais,
para que pudesse decidir com a sua
sensibilidade, equilíbrio e
independência, longe do princípio
segundo o qual o que não está nos
autos não existe.
Mesmo que na decisão do Conselho de Sentença seja divergente do pensamento do juiz, este não poderá alterar o veredicto de ofício. Caberá ao Ministério Público o poder de recorrer da decisão para que o júri seja anulado e proceda a novo julgamento. Caso recorra e novamente a decisão dos jurados for divergente da do juiz, mais uma vez o veredicto do conselho de sentença será mantido, por entender que a decisão destes é soberana. 
passa a sair a Gazeta do Rio de Janeiro, na Impressão Régia então recém-instalada no território do Novo
Mundo, com a chegada da Corte Portuguesa".

\subsection{A LIBERADE DE MANIFESTAÇÃO DO PENSAMENTO COMO DIREITO FUNDAMENTAL}

O direito a liberdade de expressão está contido no inciso IX do art. $5^{\circ}$ da Constituição Federal, o qual dispõe sobre os direitos e as garantias individuais. Em solo pátrio, entende-se como liberdade de imprensa o direito a informação, que abrange o direito de informar, se comunicar ou mostrar sua opinião. Como também o direito de ser informado. Todos estes são derivados do direito a liberdade de manifestação do pensamento e quando a imprensa usa deste direito, surge então o direito a liberdade de imprensa.

No entanto, esta liberdade não é ilimitada. Mesmo verificando a importância da imprensa para a sociedade e seu desenvolvimento, a informação mesmo que essencial não poderá jamais fugir do seu verdadeiro papel, que é o de oferecer ao público informações verídicas e suficientes para formar opinião pública, principalmente no que diz respeito aos crimes dolosos contra a vida.

\section{A INFLUÊNCIA DA MÍDIA NAS DECISÕES DO TRIBUNAL DO JÚRI}

$$
\text { É comum observarmos que os }
$$
crimes dolosos contra a vida têm muita repercussão na mídia, o que acaba por influenciar nas opiniões de quem assiste. Diante da grande visibilidade, acontece que às vezes essas informações exacerbadas acabam por influenciar as decisões do Conselho de Sentença.
Sobre a influência da mídia nas decisões do Tribunal do Júri, Prates e Tavares (p.34, 2008), asseveram que:

Alguns setores da mídia vistos como supostamente "justiceiros", antes de qualquer diligencia necessária publicam o nome de possíveis suspeitos, atribuindo-Ihes o condão de "acusados" ou mesmo "réus", sem que estes estejam respondendo ainda sequer a um processo. Carnelluti já descrevia o que significava para uma pessoa responder um processo, tendo ou não culpa por um fato: para saber se é preciso punir, punese com o processo. O cidadão nestas circunstancias, mesmo que teoricamente 
acobertado constitucionalmente pelo princípio da presunção e inocência, se vê em realidade apontado como "culpado" pelos meios de comunicação de massa, sofrendo enorme exposição e o encargo de poder enfrentar um Conselho de Sentença maculado por um "jornalismo investigativo" nem sempre ético e harmonizado com a realidade dos fatos ditos "apurados".

"De acordo com a Constituição

Federal, BRASIL 1988, está previsto no art. 5ำ, inciso LVII: ninguém será culpado até o trânsito em julgado de sentença penal condenatória". A Carta Magna prevê, portanto, a presunção da inocência até sentença penal condenatória provando o contrário. No entanto, é fácil observamos o juízo feito pela mídia, onde na maioria das vezes ela já dá sua sentença condenatória e - culpado acaba por sofrer um julgamento pela opinião.

O direito de informar, ou ainda, a liberdade de imprensa leva à possibilidade de noticiar fatos, que devem ser narrados da maneira imparcial. A notícia deve corresponder aos fatos, de forma exata e factível para que seja verdadeira, sem a intenção de confundir o receptor da mensagem, ou ainda, sem a intenção de formar nesse receptor uma opinião errônea de determinado fato (PRATES e TAVARES, p. 34,2008).

Quando nos deparamos com essas matérias jornalísticas abordando crimes dolosos contra a vida e em alguns casos fazendo o préjulgamento, nos colocamos diante da existência de dois princípios inerentes ao cidadão: a liberdade de expressão e o da dignidade humana. Entende-se que em casos de colisão de princípios, é necessário o distanciamento de um em detrimento do outro.

Neste sentido, algumas indagações surgem, tais como as suscitadas por Carla Melo (p. 106, 2010):

Pois como não se deixar influenciar se o que eles fazem é justamente tentar condenar de todas as formas? Como poderiam jurados leigos, que não tem acesso ao processo, não sabe do trâmite, não tem acesso a tudo o que foi colhido até então, não conhece sobre as normas da lei, decidindo assim por mera opinião própria, não se baseando no direito e na forma judicial julgar, tendo base no que viu na mídia e no depoimento das partes apenas 0 depoimento com a acusação e defesa, utilizando-se da malícia para convencêla de sua tese?

Questiona-se ainda, se essa é a democracia que se busca colocar pessoas para compor o Conselho de Sentença sem conhecimento algum? Pessoas estas que irão tratar da liberdade do indivíduo que é um bem fundamental. Seria essa a intenção do legislador ao considerar o instituto do Tribunal do Júri como cláusula pétrea? $\mathrm{Na}$ atual conjuntura que se encontra, seria importante também analisar com maior cuidado esta questão. 


\subsection{CASOS CONCRETOS}

Muitas vezes 0 exagero na atuação da mídia ultrapassa os limites éticos, como por exemplo, nos casos em que um jornalista investigativo passa a narrar uma atuação policial de forma política, ou até mesmo julgadora, onde se cria vítimas e réus no contexto. E é nestas ocasiões que o princípio da presunção de inocência sai de cena para dar espaço ao princípio da liberdade de imprensa.

De acordo com as palavras de Juliana Câmara (p. 271, 2013) "quando a cobertura jornalística recai sobre acontecimentos afetos ao sistema penal, 0 funcionamento desse mecanismo difusor de notícias esbarra em direitos individuais expressamente agasalhados pela Carta Magna".

Quando os veículos de comunicações expõem incansavelmente os envolvidos em crimes de grandes repercussões, as garantias e direitos fundamentais destes podem ser comprometidos, bem como influenciar a opinião dos populares, dentre estes os que podem vir a compor o Conselho de Sentença do Tribunal do Júri. Neste sentido, e a titulo exemplificativo, importante trazer a tona dois casos de grande repercussão nacional graças à exposição incessante da mídia.

A problemática está no fato de que se mesmo que um acusado não fosse condenado pelo Tribunal do Júri, o mesmo já teria sua condenação pela sociedade graças a uma verdade criada pela mídia.

O caso da menina Isabella Nardoni, que veio a falecer após ser jogada do sexto andar de um prédio pelo pai e a madrasta em 2008, se tornou um dos casos de maior repercussão nacional nos últimos anos. Além das circunstâncias: a morte brutal e fria de uma criança de 05 anos, as notícias eram atualizadas a todo 0 momento, dando oportunidade para todos poderem acompanhar o caso e os envolvidos e, com isso, formar sua opinião e juízo.

Tudo era acompanhado de perto e com muita ênfase: os conteúdos dos depoimentos, os resultados das perícias, comentários de juristas e especialistas, a vida dos suspeitos. Estes últimos eram apresentados como suspeitos ou investigados, no entanto, o teor das reportagens dava como certa a culpa do casal pelo assassinato da criança. 
Diante dos fatos, "inúmeras pessoas se reuniam em vários locais para protestar contra o casal suspeito, clamando por justiça e os chamando de assassinos, chegando inclusive a incitar o linchamento público dos suspeitos" (MANZINI, 2008). Por fim, o julgamento do casal ocorreu em março de 2010 e foram condenados há 31 anos, um mês e 10 dias e 26 anos, 08 meses de prisão, respectivamente, 0 pai e a madrasta da criança. A condenação foi comemorada por diversas pessoas, chegando inclusive a ocorrer comemoração em praça pública.

Acerca do julgamento do casal Nardoni, Muniz Sodré salienta algumas particularidades, tais como:

[...] a falta de escuta das vozes favoráveis. A mídia não é, porém, tribunal do júri. Cabem-lhe os fatos e as diligencias em curso, mas sem julgar, a despeito do que possa parecer evidente aos olhos de todos. Seriam adequadamente jornalístico que se ouvissem as falas de membros das famílias dos acusados, como pai, irmão, etc. Daí poderá surgir algo capaz de jogar alguma luz socialmente útil ao conhecimento das distorções perversas da consciência, daquilo que, no português quinhentista, se chamava de maleza (MUNIZ, s.p, 2010).

Outro caso notório que vale ressaltar na ocasião é o desaparecimento de Eliza Samudio ocorrido em 2010. Na época a vitima era amante do ex-goleiro Bruno, do
Flamengo. O motivo para o crime seria a recusa do goleiro em assumir a paternidade do filho da modelo, fruto da relação de ambos.

$$
\text { Informações constam que a }
$$
modelo teria informado à família que iria a chácara do jogador a pedido do próprio, que fica em Contagem, Estado de Minas Gerais. Depois disso, a vítima desapareceu e até hoje não há vestígios de seu corpo para que fosse comprovada a morte, sendo esta presumida. $\mathrm{O}$ julgamento ocorreu em março de 2013 e condenou o ex-atleta a 22 anos e três meses de reclusão. Foram condenados ainda, outros dois comparsas que confessaram a participação.

É curiosa a inversão de papéis que a mídia também é responsável por fazer. No caso em questão, o ex-goleiro Bruno era apresentado como vítima e a Eliza era apresentada como uma mera garota de programa. Após as investigações, algumas descobertas e veiculação na imprensa, o primeiro passou a ser visto como um assassino frio e cruel e a outra como uma modelo com sonhos e objetivos de vida.

Portanto, é possível observar com os exemplos narrados acima, que quando se tratam de casos de grande repercussão, a mídia tem um papel 
mais amplo do que apenas informar. Seja de forma proposital ou não, a imprensa exerce um papel de manipular fatos, idéias e fazer com que a sociedade emita seu juiz de valor. A

\section{CONSIDERAÇÕES FINAIS}

Quando a mídia aborda notícias de crimes ou violência, é natural a atenção e curiosidade que estas despertam no indivíduo. Sendo assim, é de conhecimento da imprensa que a veiculação destas matérias vende, rendem lucros, o que a faz explorar o assunto a fundo. No entanto, merece cuidado quando se trata da divulgação destas notícias, pois visando o rápido retorno, muitas vezes apelam para o sensacionalismo e acabam deturpando os fatos, e com isso ferindo o princípio da dignidade humana.

Em se tratando de direitos fundamentais do cidadão, é possível afirmar que nenhum deve se sobrepor ao outro. E no caso em tela, podemos observar a colisão dos princípios da dignidade da pessoa humana, o princípio da liberdade de imprensa e ainda, o princípio da presunção e inocência.

No entanto, estamos diante de um caso de exceção. Aqui se observa mídia, por vezes, é a responsável por fazer a condenação antecipada dos acusados e vinda a influenciar, por vezes, nas decisões dos jurados.

a colisão dos princípios supracitados e, quando isto acontece, o mais concebível é que a liberdade de imprensa recue e dê preferência aos outros dois princípios fundamentais: o da dignidade da pessoa humana e o da presunção de inocência.

Diante da ausência de senso crítico, de conhecimento ou mesmo de ingenuidade de grande parte da sociedade, as notícias veiculadas pela mídia sempre chegam ao interlocutor com a presunção de veracidade, o que faz com que as pessoas logo façam seus julgamentos. $E$ quando isso acontece, além de ferir a dignidade e privacidade do condenado, pode também levar a interferir nas investigações e acabar por prejudicalas.

É imprescindível que aos jurados não seja incutida qualquer tipo de influência, devendo os mesmos ser neutros e julgarem apenas de acordo com os fatos e provas apresentadas no 
Tribunal do Júri. Caso a influência ocorra, pode ocorrer um julgamento errôneo, o que vem acarretar danos irreparáveis na vida do condenado.

Ressalte-se, portanto, que 0 presente trabalho não pretende jamais se opor ao trabalho prestado pela mídia e muito menos a liberdade de imprensa. Pelo contrário, reconhece a importância da atuação destes para a sociedade, levando informações e denúncias sempre que necessário. No entanto, o que está em análise é o trabalho tendencioso, apelativo e sensacionalista de alguns meios, que por ambição levam informações equivocadas aos cidadãos que formam um juízo de valor antes do tempo.

Por fim, reconhecendo a importância e eficácia da mídia para a sociedade, é notório que nos casos dos crimes de competência do Tribunal do Júri, quando divulgados pelos meios jornalísticos, tendem a formar opiniões da sociedade. E, tendo em vista que o Conselho de Sentença do Tribunal do Júri é formado por leigos da sociedade civil, podem estes ser influenciados nos casos de informações errôneas da mídia, o que vem a acarretar na decisão destes.

\section{REFERÊNCIAS}

BRASIL. Código de Processo Penal. Disponível em: <http://planalto .gov.br/ccivil_03/dec reto-lei/del13689.htm>. Acesso em: 18 de abr. de 2016.

, constituição da República Federativa do Brasil. Disponível em: <http://planalto.gov.br/ccivil_03/constituição.htm>. Acesso em: 18 de abr. de 2016.

BUDÓ, Marília Denardin. Mídia e crime: a contribuição do jornalismo para a legitimação do sistema penal. UNIrevista - Universidade do Vale dos Sinos, São Leopoldo/RS, vol. 1, n. 3, jul/2006. p. 8. Disponível em: . Acesso em: 18 abr. 2013.

CÂMARA, Juliana de Azevedo Santa Rosa. Sistema penal e mídia: breves linhas sobre uma relação conflituosa. Revista Esmese - Escola Superior da Magistratura de Sergipe, Aracaju/SE, n. 17, 2012. p. 265-289.

CAMARGO, Aline. Para a mídia, não há suspeitos. Blog "Plural: Observatório de Comunicação e Cidadania". 31 de maio de 2011. Disponível em: <http://www2.faac.unesp.br/blog/obsmidia/2011/05/31/para-a-midia-nao-hasuspeitos/>. Acesso em: 19 de abr. de 2016. 
CAPEZ, Fernando. Curso de Processo Penal. São Paulo: Saraiva, 2009.

DINIZ, Maria Helena. Dicionário Jurídico. Vol. 01. São Paulo: Saraiva, 1998.

MANZINI, Gabriela. Suspeita de agressão paterna contra menina indefesa acirra revolta. Folha Online, São Paulo, 20 de abril de 2008. Disponível em <http://www1.folha.uol.com.br/folha/cotidiano/ult95u393882.shtml>. Acesso em: 19 de abr. de 2016.

MELLO, Carla Gomes de. Mídia e Crime: Liberdade de Informação Jornalística e Presunção de Inocência. Vol. 05. №. 02. Londrina: Revista de Direito Público, 2010.

PRATES, Flávio Cruz; TAVARES, Neusa Felipim dos Anjos. A influência da mídia nas decisões do Conselho de Sentença. Direito \& Justiça. Porto Alegre. Vol. 34, no 02, jul/dez, $2008 . \quad$ Disponível em: $<$ http://revistaseletronicas.pucrs.br/ojs/index.php/fadir/article/view/5167>. Acesso em: 18 de abr. de 2016.

Recebido em: 24/05/2016

Aprovado em: 22/06/2017 